DOI $10.31168 / 0440-4.55$

\title{
DESANKA MAKSIMOVICH: THE GREATEST SERBIAN POET
}

\begin{abstract}
:
The article is devoted to Desanka Maksimovich (1898-1993), the greatest Serbian poet of the 20th century, author of storybooks for children and a translator. The themes of her rich poetic work, include love lyrics, the subtlety of a female soul's experiences, the understated beauty of her native land, people's courage during the Second World War and past glories from history. The poems' depth of meaning is combined with subtle lyrical imagery and musicality. Desanka Maksimovich's contemproraries called her "the face of the Serbian poetry". She was recognized by UNESCO as a "Personality of Culture of the 20th Century".
\end{abstract}

\section{Keywords:}

Desanka Maksimovich, Serbian poetry, anti-fascist theme, women's lyrics, elegy, prose poet.

АННОтация: А.Г. ШЕШКЕН. «КРУПНЕЙШАЯ СЕРБСКАЯ ПОЭТЕССА ДЕСАНКА МАКСИМОВИЧ».

Десанка Максимович (1898-1993) - крупнейшая сербская поэтесса ХХ в., автор произведений для детей, переводчик. Любовная лирика и тонкость переживаний женской души, неброская красота родного края, мужество народа в годы Второй мировой войны, славное историческое прошлое - темы ее богатого поэтического творчества. Глубина содержания сочетается в нем с тонкостью лирического рисунка и музыкальностью звучания. Современники назвали ее «лицом сербской поэзии». Она была признана ЮНЕСКО «Личностью культуры ХХ века».

Ключевые слова:

Десанка Максимович, сербская поэзия, антифашистская тема, женская лирика, элегия, стихотворения в прозе.

$\mathrm{D}$ esanka Maksimovich (1898-1993) was the greatest Serbian writer of her time and author of numerous collections of poems, several novels and storybooks for children. She made a great contribution to developing the expressivity of the Serbian poetic language, enriching it with new subtle images, and managing to explore, like no one else, the inner world of the female soul. In 1998, UNESCO recognized Maksimovich as a "Personality of Culture of the 20th Century".

She was born into the family of a rural teacher and the daughter of a priest. Her love for literature was instilled in her by her father and Sima Pandurovich, a high school teacher and a poet. While studying at the philological faculty of the University of Belgrade, she was strongly influenced by the literary critic and 
university teacher Bogdan Popovich, under whose guidance she wrote her thesis. It was on his recommendation that, after a year working as a teacher in Dubrovnik, the aspiring poet received a scholarship from the French government and majored in art history at the Sorbonne (1924-25). Upon her return, she worked as a teacher in Belgrade, and after World War II, she worked in the country's Ministry of Education, and as a writer too.

Her first publication appeared in 1920 in the Belgrade magazine Misao ("Thought"), and her first poetry collection, Pesme ("Songs"), was published in 1924 and was favorably received by critics. The famous literary historian M. Kashanin called Maksimovich a gifted poet with an innate poetic gift and sense of style. In the in-

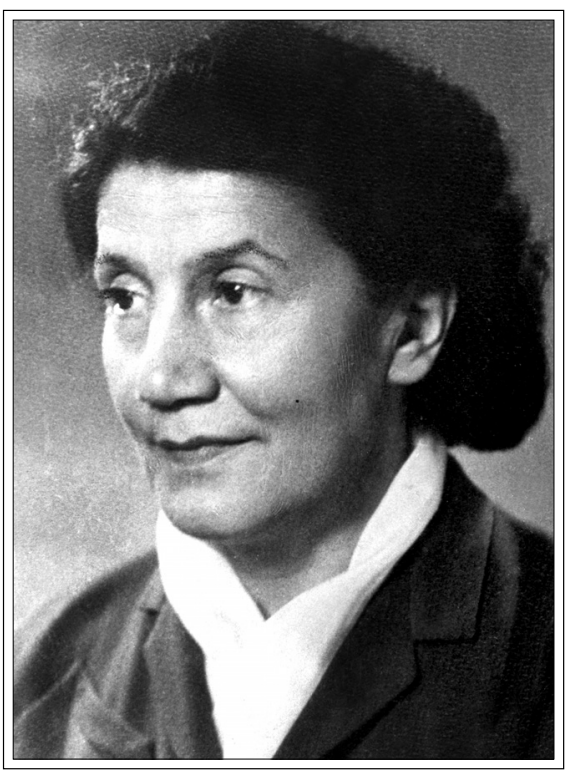

Desanka Maksimovich terwar period her fame increased markedly after the publication of the poetry collections Zeleny Vitez ("The Green Knight", 1930), Gozba na Livadi ("Feast in the Meadow", 1932), Nove Pesme ("New Poems", 1936) and the collection of short stories Kako oni zhive ("How they live", 1935).

She did not join any of the literary movements of the time and scarcely participated in poetry circles. The exception was the Russian-Serbian circle "Steps" (1927), whose members (M. Kashanin, G. Krklets, M. Pogodin, E. Tauber and others) were mainly engaged in poetic translation. In those years she developed a deep interest in Russia and Russian literature, explainable by her personal circumstances: she became the wife of a Russian emigrant, the translator S. Slastikov.

Without entering into literary polemics, the poet developed her own unique style, and mastered and developed those aspects of 20 th century art which were close to her worldview and corresponded to the nature of her talent. It is possible to speak about her perception of and experience of impressionism in her communication of shades of feelings, and changing states of nature and about the cult of beauty inherent in modernity. At the same time, as a citizen Maksimovich was inherently intolerant of evil and hypocrisy. Her verse is distinguished by a calm, almost narrative, intonation and a special melody, a subtle rhythmic pattern, highlighting the numerous changing nuances of mood. Her poetic language is no stranger to metaphor. It is very rich in its use of synonyms; there is an abundance of epithets, comparisons, metaphors, fresh and memorable images that do not violate the norms of classical syntax and grammar. 
Maksimovich's lyrics are filled with intimate experiences and penetrate deeply into the inner world of the personality; they are woven from half tones. Everything deliberate and loud is alien to the lyrical hero, immersed in contemplation of the world. Pesma ("Poem") emphasizes that the object and source of poetry seem outwardly simple and inconspicuous things. The two main themes of the poet's pre-war lyrics, love and nature, are closely related to another recurrent theme: that of the homeland. At first glance, it sounds unremarkable, but in fact it has a rich range of motives and nuances. Here are pictures of her native land, and memories of her childhood and family home, her father who died during the First World War (the cycle Sjećanje na oca / "Remembering my Father") and thoughts about her own destiny. During this period the key genres of Maksimovich's work are elegy and poem in prose ("The Green Knight").

The Second World War and the heroic resistance of the Serbian people to fascist aggression introduced new themes into Maksimovich's poetry: Pesme $O$ poroblyonem blebu ("Song on the enslaved bread"), Srbija je velika tayna ("Serbia is a great mystery"), Srbija se budi ("Serbia is awakening"), Bayka o ustanichkoj pushki ("The Tale on the rebel's gun"). The poet's lyrics acquire a tragic intensity, filled with civic pathos and pride in her people. The most significant work of this period - the poem Krvava Bajka ("Bloody Tale", 1941) was a response to the mass execution of almost the entire male population of the city of Kraguyevats in October 1941. Among the victims were several classes of high school students who were put to death together with their teacher straight from their lessons. The contrast of everyday school life and the heroic deaths of the children gives the poem a highly tragic ring. The emotional impact of the work is enhanced by the calm epic intonation, the sparse adjectives, details of school life and general biographical details of the victims. The self-control of children who walk with firm steps and equanimity to their execution engenders admiration for the courage of the Serbian people and makes an important contribution to the formation of the aesthetic ideal of the era, when writers praised the strength and greatness of a person whose self-sacrifice became the measure of beauty.

Maksimovich was one of the first to address the motif of mass martyrdom for faith and homeland, something which has a rich tradition in Serbian folklore and literature. Her poetry of those years is based on the oral folk tradition in terms of genre, choice of expressions and poetic dimensions.

In the postwar years, the main thrust of Maksimovich's works was patriotic and civic poetry, in which new motifs appeared. Their thematic core was selfless resistance to the enemy and the joy of liberation. The poet's focus was on the partisan hero and a man-the-builder, who was rebuilding the destroyed country. She praised the courage of her people in the cycle Pesme o ropstvu $i$ slobodi ("Poems on Slavery and Freedom"). In the poem Otatsbino, tu sam ("I am here, my Homeland", 1951), which is dedicated to Dushitsa Stefanovich, who endured terrible torture and was executed by the Germans in October 1941, there are noticeable similarities with the poem by the Russian poet M. Aliger, "Zoya". Mak- 
simovich depicts the war as a terrible test for a person, as a time of terrible losses and deep sorrow in Obudovela nevesta ("The widowed bride"). In the patriotic lyrics of those years, she turned to the origins of the national character, contrasting the breadth of soul and sincerity of the Serbs with the "civilization" of Europeans (Balkanats / "The Balkanian").

In the 1950s-60s Maksimovich returned to the genre of lyrical confession, subtle emotional experiences, inspired by memories of childhood, contemplation of native places and reflections on the transience of life, its sorrows and joys: Miris zemlye ("The smell of the earth", 1955), Zaroblenik snova ("Prisoner of dreams", 1960), Govori tikho ("Speak softly", 1961). Reflections on the historical fate of her people and, at the same time, the dream of a world living according to laws of love and humanism, are contained in one of Maksimovich's main collections of work Tražim pomilovanje ("I demand a clemency", 1964). The book is subtitled "Lyrical discussions with the 'Lawyer' of Tsar Dushan" - a set of legal acts of 1349, established by the ruler of the Serbian medieval state during its heyday. Critics noted that the poet's story about this code of laws was intended to convey an important message for our time, one containing the great poetry of love, understanding and compassion. The collection was built as a dialogue between a ruler who gave his people fair laws and a poet who judges the world and man according to the laws of love. It is an epic cycle consisting of about 70 verses. Its main idea is the contradiction between a rational attitude to life and the infinite complexity of its real manifestations, when the most just law can turn into cruelty. It contains the poet's prayers for "royal roads", for "the land on which the army sets foot", for "a runaway slave", and she asks for mercy for the "shepherdess who is not called by her father", for "weddings without a wedding", to "committed adultery", to "barren women", to the misunderstood, naive, persecuted and insulted. The collection is written in free verse but has an internal rhythm. Its lexical richness is based on the use of archaisms, dialects and modern language. For Maksimovich, one's native language is the primary link between the distant past and the present, when a person is in no less need of mercy.

After a long absence Maksimovich published another collection of poems, Nemam vishe vremena ("I Have No More Time", 1973), which heralded a new stage in her work, when "there is no time for long phrases and long conversations". It was followed by more than a dozen poetry collections: Letopis Perunovih potomaka ("Annals of the descendants of Perun", 1976), Pamtichu sve ("I will remember everything", 1988), Ozon zavichaja ("Ozone of the native land", 1990), etc. The publication in 1987 of Maksimovich's collections Babino Leto ("Indian Summer") and Festival snova ("Festival of Dreams") sparked great interest among readers. They contain sonnets with reflections and memories of life lived and of the bitter loss of friends and relatives.

Maksimovich's poetry continues to be highly valued in her home country. For the centenary of the poet's birth, a library fund Zaduzbbina was established 
in Belgrade, named after her. It regularly hosts the so-called Desankinii Majski Razgovori ("Desanka's May Conversations") timed to her birthday: academic and public readings, the materials of which are published in separate collections. Maksimovich's fame is also widespread abroad. In Russia, in particular, her poetry is known due to translations by such wordsmiths as V. Kornilov, Joseph Brodsky, Anna Akhmatova, David Samoylov, Boris Slutsky, Margarita Aliger, Bella Akhmadulina, Leonid Martynov and others.

Translated by Igor Kaliganov

\section{BIBLIOGRAPHY}

Dzh'ordzh'evich L'. Pesnichko delo Desanke Maksimovich. Beograd, 1971.

Blechich M. Zhivot Desanke Maksimovich prachen pesmom. Beograd, 1998.

Blechich M. Sa Desankom Maksimovich. Prir. L'. Andrich. Novi Sad, 1989.

Markovich S.Zh. Poeziya Desanke Maksimovich. Beograd, 1990. Desanka Maksimovich u svom kn'izhevnom vremenu // Zbornik radova. Desankini Maiski razgovori. 15-16 maiya 1995. Priredio S.Zh. Markovich. Beograd, 1995.

Sibinovich M. Novi aspekti kn'izhevnog dela Desanke Maksimovich. Beograd, 1999,

Desanka Maksimovich u detsinitsii 1993-2003. Priredio S.Zh. Markovich. Beograd, 2004.

Ognev V. Desanka Maksimovich // Ognev V. Sem' tetradei. Etyudi o literature sotsialisticheskhih stran Yevropy. Moskva, 1987. Pp. 280-89.

Shcheglov S. Desanka - velikaya taina. Ocherk. Krasnoyarsk, 1998.

Shcheglov S. Ostavlyayu vam tol'ko slova. Krasnoyarsk, 2008.

\section{ILLUSTRATIONS}

1. A photo of Desanka Maksimovich.

2. A photo of Desanka Maksimovich in her youth.

3. Sima Pandurovich, the Serbian poet and gymnasium teacher, who noticed D. Maximovich's talent.

4. Bogdan Popovich (1863-1944): Serbian critic, professor of the Philological Faculty of the University of Belgrade, scientific adviser of D. Maksimovich.

5. The cover of the Serbian edition of Desanka's poetry collection.

6. A Monument in Valevo to Desanka Maksimovich: "The Face of Poetry".

7. Monument to Desanka Maksimovich in Belgrade's Tashmaydan Square.

8. A street, named after Desanka Maksimovich in Belgrade.

9. The annual Belgrade memorial day "Desanka's May Conversations." Laying flowers at the grave of the poet. 